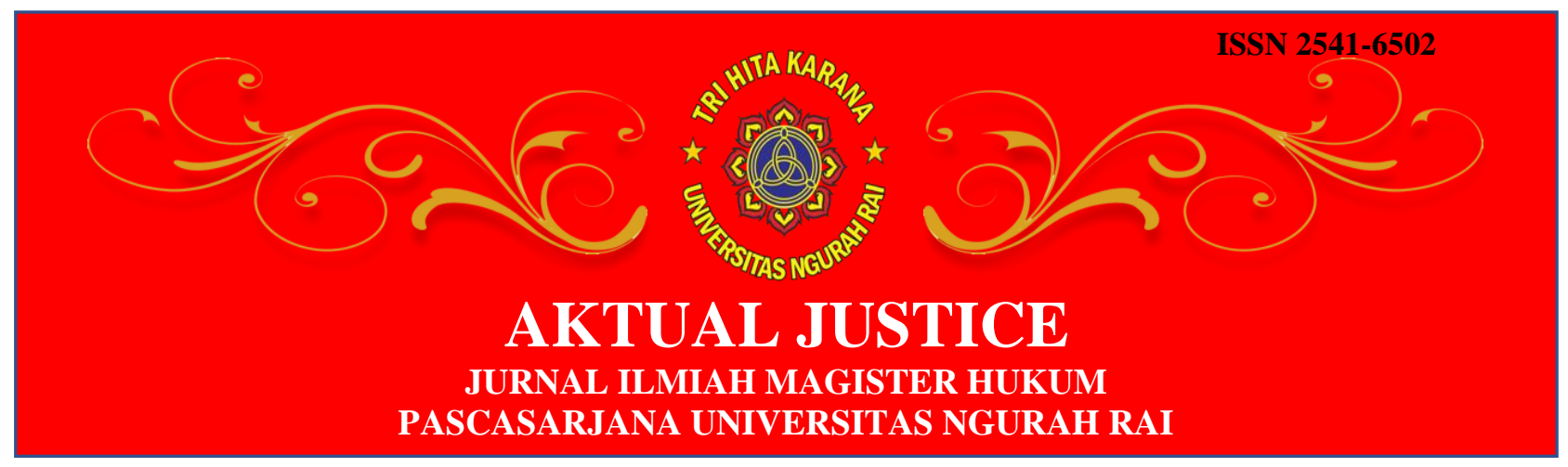

\title{
Kedudukan Otoritas Jasa Keuangan Pada Perusahaan \\ Modal Ventura Asing
}

\author{
Anak Agung Sagung Ngurah Indradewi
}

Fakultas Hukum Universitas Dwijendra, Email : sagungindradewi@gmail.com

\begin{abstract}
The juridical basis for supervision of foreign venture capital companies is contained in the provisions of Capital Law No. 21 of 2008 concerning the Financial Services Authority (OJK), Presidential Regulation No. 9 of 2009 concerning Financing Institutions and Minister of Finance Regulation No. 18 / PMK.010 / 2012 concerning Venture Capital Companies. Foreign venture capital companies that invest directly in Indonesia are a form of foreign investment. This is inseparable from the wide scope of foreign capital, which is defined as capital owned by foreign countries, individual foreign citizens, foreign business entities, foreign legal entities, and / or Indonesian legal entities whose capital is partly or wholly owned by foreign parties. Supervision of foreign investment is carried out by the Investment Coordinating Board in accordance with the provisions of Law No. 25 of 2007 concerning Investment. In accordance with the provisions in Permenkeu No. 18 / PMK / 0.10 / 2012 explained that the scope of supervision of venture capital carried out by the OJK is only limited to PMV Indonesia (Cooperatives or Limited Liability Companies). The implication is that OJK cannot supervise foreign PMVs that carry out direct financing. Because financing activities by foreign venture capital companies have intersecting rules, it is appropriate that foreign venture capital regulations only follow one specific rule. The regulation regarding financing institutions is only regulated in a Presidential Regulation. Although hierarchically, the status of the Perpres is an implementing regulation of the Law, the substance it regulates is not identical with the provisions of the Law which mandates it. Therefore, the provisions regarding financing activities should be regulated in a separate Law Keywords: Financial Services Authority, Foreign Venture Capital Company.
\end{abstract}

\footnotetext{
Abstrak

Dasar keadilan Pancasila terdapat pada butiran 2 dan 5 dimana yang berbunyi sila kedua kemanusiaan yang adil dan beradab dan sila keempat keadilan bagi seluruh rakyat indonesia. Nilai kemanusiaan yang adil dan beradab, bahwa kesadaran sikap dan perilaku yang sesuai dengan nilai-nilai moral dalam hidup bersama atas dasar tuntutan hati nurani dengan memperlakukan sesuatu hal sebagaimana mestinya. Manusia perlu diperlakukan sesuai dengan harkat dan martabatnya, sebagai makhluk Tuhan yang sama derajatnya dan sama hak dan kewajiban asasinya. Berdasarkan nilai ini, secara mutlak ada pengakuan terhadap hak asasi manusia. Nilai keadilan sosial bagi seluruh rakyat Indonesia, mengandung makna sebagai dasar sekaligus tujuan yaitu tercapainya masyarakat Indonesia yang adil dan makmur secara lahiriah maupun batiniah. Berdasar pada nilai ini, keadilan adalah nilai yang amat mendasar yang diharapkan oleh seluruh bangsa. Negara Indonesia yang diharapkan adalah negara Indonesia
} 
yang berkeadilan. Keadilan diuraikan secara mendasar oleh Aristoteles yakni untuk mengetahui tentang keadilan dan ketidak adilan harus dibahas tiga hal utama yaitu tindakan apa yang terkait dengan istilah tersebut, apa arti keadilan, dan diantara dua titik ekstrim apakah keadilan itu terletak.

Kata Kunci : Keadilan, Pancasila, Teori Aristoteles.

\section{Pendahuluan}

Investasi merupakan salah satu dasar untuk mencapai pembangunan nasional yang berkesinambungan. Pembangunan nasional merupakan pencerminan kehendak untuk terus-menerus meningkatkan kesejahteraan dan kemakmuran rakyat Indonesia secara adil dan merata, serta mengembangkan kehidupan masyarakat dan penyelenggaraan negara yang maju dan demokratis berdasarkan Pancasila dan UndangUndang Dasar Negara Republik Indonesia Tahun 1945 (UUD NRI 1945).

Pembangunan nasional yang berdasarkan Pancasila dan UUD NRI 1945 merupakan pencerminan kehendak yang dituangkan dalam Garisgaris Besar Haluan Negara yang menegaskan bahwa "Sasaran umum Pembangunan Jangka Panjang Kedua adalah terciptanya kualitas manusia dan kualitas masyarakat Indonesia yang maju dan mandiri dalam suasana tenteram dan sejahtera lahir batin, dalam tata kehidupan masyarakat, bangsa, dan negara yang berdasarkan Pancasila, dalam suasana kehidupan bangsa Indonesia yang serba berkeseimbangan dan selaras dalam hubungan antara sesama manusia, manusia dengan masyarakat, manusia dengan alam dan lingkungannya, manusia dengan Tuhan Yang Maha Esa". Investasi di bidang ekonomi merupakan sasaran Pembangunan Jangka Panjang Kedua, antara lain, adalah terciptanya perekonomian yang mandiri dan andal, dengan peningkatan kemakmuran rakyat yang makin merata, pertumbuhan yang cukup tinggi, dan stabilitas nasional.

Saat investasi asing pertama kali diatur di Indonesia melalui Undang-Undang No. 1 Tahun 1967, ada dua istilah yang sering muncul, 
yaitu Penanaman Modal Asing dan Modal Asing. Saat itu, istilah penanaman modal asing diartikan sebagai aktivitas pendanaan yang hanya meliputi modal asing secara langsung, menurut Undang-Undang dan untuk digunakan menjalankan perusahaan di Indonesia. Pengertian secara langsung artinya penanaman modal dilakukan tidak melalui pasar modal atau pembelian saham. Penanaman modal asing tersebut dilakukan saat perusahaan pertama kali didirikan. Makna menurut Undang-Undang adalah modal asing yang diinvestasikan di Indonesia oleh investor asing harus didasarkan pada substansi, prosedur dan syarat-syarat yang ditentukan oleh peraturan per Undang-Undangan yang berlaku.

Setelah diganti dengan Undang-Undang No. 25 Tahun 2007, dalam Pasal 1 angka 9 menyebutkan bahwa penanaman modal asing merupakan kegiatan menanam modal untuk melakukan usaha di wilayah negara Republik Indonesia yang dilakukan oleh penanam modal asing, baik yang menggunakan modal asing sepenuhnya maupun yang berpatungan dengan penanam modal dalam negeri.

Pasar Modal bertujuan menunjang pelaksanaan pembangunan nasional dalam rangka meningkatkan pemerataan, pertumbuhan, dan stabilitas ekonomi nasional ke arah peningkatan kesejahteraan rakyat. Dalam rangka mencapai tujuan tersebut, Pasar Modal mempunyai peran strategis sebagai salah satu sumber pembiayaan bagi dunia usaha, termasuk usaha menengah dan kecil untuk pembangunan usahanya, sedangkan di sisi lain Pasar Modal juga merupakan wahana investasi bagi masyarakat, termasuk pemodal kecil dan menengah.

Istilah investasi atau penanaman modal merupakan istilah-istilah yang dikenal, baik dalam kegiatan bisnis sehari-hari maupun dalam bahasa perundangundagan. Istilah investasi merupakan istilah yang lebih popular dalam dunia usaha, sedangkan istilah penanaman modal lebih banyak 
digunakan dalam bahasa perundang-undanga. Investasi berasal dari kata invest yang berarti menanam, menginvestasikan atau menanam uang. ${ }^{1}$

Istilah investasi atau penanaman modal merupakan istilah-istilah yang dikenal, baik dalam kegiatan bisnis sehari-hari maupun dalam bahasa perundang-undagan. Istilah investasi merupakan istilah yang lebih popular dalam dunia usaha, sedangkan istilah penanaman modal lebih banyak digunakan dalam bahasa perundang-undanga. Namun, pada dasarnya kedua istilah tersebut mempunyai pengertian yang sama sehingga kadangkadang digunakan secara interchangeable. ${ }^{2}$

Pasal 1 Undang-undang Nomor 25 Tahun 2007 tentang Penanaman Modal, menyebutkan bahwa Penanaman Modal adalah segala bentuk kegiatan Penanaman modal, baik oleh penanaman modal dalam negeri maupun penanaman modal asing untuk melakukan usaha di wilayah Negara Republik Indonesia.Dalam pasal 12 UU Penanaman Modal, dinyatakan bahwa semua bidang usaha atau jenis usaha terbuka bagi kegiatan penanaman modal, kecuali bidang usaha atau jenis usaha yang dinyatakan tertutup dan terbuka dengan persyaratan. Dari ketentuan ini, dapat dimaknai bahwa UU Penanaman Modal hanya mengatur tentang batasan terhadap jenis usaha yang akan didirikan di Indonesia, tanpa mensyaratkan jenis usaha asalnya di luar negeri. Ketentuan ini kemudian menimbulkan akibat bagi perusahaan pembiayaan asing/Perusahaan Modal Ventura Asing (PMV Asing).

Mereka dapat secara langsung melakukan pembiayaan/penyertaan modal pada usaha yang ada di Indonesia, tanpa harus terlebih dahulu berpatungan untuk membuat PMV Indonesia. Hal

\footnotetext{
166.

${ }^{1}$ Halim, A. (2003). Kamus Lengkap 1 Milyar Inggris-Indonesia. Surabaya: Sulita Jaya. h.

${ }^{2}$ Supanca, I.B.R. (2006). Kerangka Hukum dan Kebijakan Investasi Langsung di Indonesia. Bogor: Ghalia Indonesia. h.1.
} 
itu dikarenakan, pembiayaan yang dilakukan secara langsung oleh PMV asing akan dianggap sebagaimana penanaman modal asing biasa.

Sebagaimana yang berlaku di Indonesia, landasan hukum bagi perseroan terbatas adalah Undang-Undang No. 40 Tahun 2007 (UU PT). Apapun usahanya, selama ia didirikan dengan bentuk perseroan terbatas, maka ia harus terikat pada UU PT. Hal ini memiliki dampak apabila suatu perseroan didirikan berdasarkan UU PT, maka perusahaan tersebut memiliki kebangsaan Indonesia \& berlaku serta tunduk terhadap hukum Indonesia.

Akibat dari adanya klausul tersebut, apabila ada perusahaan asing yang memiliki usaha inti (core business) pembiayaan, misalnya modal ventura, yang ingin melakukan pembiayaan ke Indonesia, maka ia tidak dapat melakukan pembiayaan secara langsung. PMV asing tersebut harus berpatungan (joint ventures) terlebih dahulu dengan entitas Indonesia untuk menjadi PMV Indonesia. Baru kemudian, ia dapat melakukan pembiayaan di Indonesia.

Permasalahan tersebut di atas menimbulkan masalah dalam hal pengawasan. Awalnya, pengawasan terhadap usaha lembaga pembiayaan merupakan wewenang dari Badan Pengawas Pasar Modal dan Lembaga Keuangan (Bapepam LK). Setelah disahkannya Undang-Undang No. 21 Tahun 2011 Tentang Otoritas Jasa Keuangan (OJK), pengawasan terhadap usaha lembaga pembiayaan beralih seluruhnya kepada OJK. UU OJK tersebut mengatur, bahwasanya pengawasan terhadap lembaga pembiayaan mengikut kepada peraturan per Undang-Undangan yang mengatur mengenai lembaga pembiayaan. Sebagaimana telah disebutkan di atas, usaha lembaga pembiayaan, dalam hal ini modal ventura haruslah berbentuk badan hukum Indonesia. Dari hal tersebut, maka dapat ditarik kesimpulan bahwa OJK hanya dapat melakukan pengawasan terhadap perusahaan modal ventura yang telah berbadan hukum Indonesia saja. Atas 
ketentuan tersebut, OJK tidak dapat melakukan pengawasan terhadap perusahaan modal ventura asing yang melakukan pembiayaan secara langsung kepada usaha yang ada di Indonesia. Hal tersebut dikarenakan pembiayaan oleh perusahaan modal ventura asing akan dianggap sebagai upaya penanaman modal asing biasa, bukan pembiayaan. Masalah ini menjadi menarik untuk dikaji. Satu sisi, sebagai institusi pengawasan terhadap jasa keuangan, OJK seharusnya memiliki wewenang untuk melakukan pengawasan terhadap upaya pembiayaan, termasuk pembiayaan lintas negara sekalipun. Namun, di sisi lain, ketentuan normatif menjelaskan segala sesuatu modal asing yang masuk ke dalam negeri merupakan domain dari penanaman modal asing, bukan pembiayaan.

\section{Metode Penelitian}

Penelitian ini menggunakan tipe penelitian hukum yuridis normatif yaitu mengkaji dan menganalisa bahan-bahan serta isue-isue hukum berdasarkan peraturan perundang-undangan. Penelitian ini dilakukan untuk memecahkan permasalahan hukum yang timbul sedangkan hasil yang akan di capai adalah preskripsi mengenai apa yang seyogyanya dilakukan. ${ }^{3}$ Dalam hal ini penelitian Kedudukan Otoritas Jasa Keuangan Pada Perusahaan Modal Ventura Asing. Metode pendekatan yang dipergunakan dalam penelitian ini menggunakan beberapa tekhnik sebagai berikut:

a. Pendekatan Undang-Undang (Statute Aproach)

Yaitu pendekatan dengan menggunakan legislasi dan regulasi. Penelitian hukum dalam level dogmatika hukum tidak dapat melepaskan diri dari pendekatan perundang-undangan karena pokok bahasan yang di

${ }^{3}$ Marzuki, P.M. (2005). Penelitian hukum. Jakarta: Prenada Media. h. 7. 
telaah berasal dari peraturan perundang-undangan. Pendekatan undangundang dilakukan dengan menelaah semua undang-undang dan regulasi yang bersangkut paut dengan Kedudukan Otoritas Jasa Keuangan Pada Perusahaan Modal Ventura Asing.

Untuk mempelajari adakah konsistensi dan kesesuaian antara suatu undang-undang dengan undang-undang lain, atau antara undang-undang dengan undang-undang dasar atau antara regulasi dengan undangundang.

b. Pendekatan konseptual (Conseptual Aproach) yaitu:

Pendekatan konseptual yaitu pendekatan yang beranjak dari pandangan-pandangan dan doktrin-doktrin yang berkembang di dalam ilmu hukum, agar menemukan ide-ide yang melahirkan pengertianpengertian hukum, dan asas-asas hukum atau argumentasi hukum yang merupakan sandaran peneliti untuk membangun argumentasi hukum dalam memecahkan isu yang dihadapi. ${ }^{4}$ Pendekatan konseptual ini digunakan untuk menemukan pandangan-pandangan dan doktrin-doktrin yang berkembang dalam ilmu hukum, kajian prinsip-prinsip hukum berkaitan dengan Kedudukan Otoritas Jasa Keuangan Pada Perusahaan Modal Ventura Asing.

\section{Hasil Dan Pembahasan}

Prof. M Sornarajah mendefinisikan penanaman modal asing adalah: "Transfer of tangible or intangible assets from one country to another for the purpose of use in the country to generate wealth under the total of partial control of the owner of the assets" ${ }^{5}$ Dari definisi tersebut dapat dimaknai bahwasanya penanaman modal asing merupakan transfer modal, baik nyata maupun

${ }^{4}$ Ibid, h. 95.

${ }^{5}$ Sornarajah, M. (2010). The International Law on Foreign Investment. 3rd Edition. New York: Cambridge University Press. h. 2. 
tidak nyata dari suatu negara ke negara lain, tujuannya untuk digunakan di negara tersebut agar menghasilkan keuntungan di bawah pengawasan dari pemilik modal, baik secara total atau sebagian. Artinya, penanaman modal asing dikonstruksikan sebagai pemindahan modal lintas negara untuk meraih keuntungan.

Dari paparan di atas, dapat dikatakan bahwasanya definisi modal asing sangatlah luas. Hal itu dikarenakan modal asing tidak hanya dalam bentuk uang, tetapi juga dalam bentuk alat-alat perusahaan dan penemuan baru, ${ }^{6}$ sedangkan dalam Undang-Undang No. 25 Tahun 2007 modal asing adalah modal yang dimiliki oleh negara asing, perseorangan warga negara asing, badan usaha asing, badan hukum asing, dan/atau badan hukum Indonesia yang sebagian atau seluruh modalnya dimiliki oleh pihak asing.

Negara asing berarti negara yang berbeda kedaulatan dengan Indonesia. Perseorangan warga negara asing merupakan individu luar negeri yang menanamkan investasinya di Indonesia. Badan usaha asing merupakan lembaga asing yang tidak berbadan hukum. Badan hukum asing merupakan badan hukum yang dibentuk berdasarkan perUndangUndangan yang berlaku di negara asing tersebut. Dalam Undang-Undang No. 25 Tahun 2007, konstruksi modal asing mengalami perubahan. Pemaknaan modal asing hanya difokuskan pada kepemilikan oleh negara asing. Artinya, Indonesia tetap menerima segala bentuk variasi modal asing, sama seperti pertama kali diatur pada tahun 1967.

Dari berbagai pengertian tentang modal asing dan penanaman modal asing yang telah dibahas di atas serta beberapa kriteria tentang penanaman modal asing dapat diambil kesimpulan bahwa Perusahaan Modal Ventura Asing yang melakukan pembiayaan secara langsung di Indonesia merupakan suatu bentuk penanaman modal asing. Dalam hal

6 Salim HS dan Sutrisno, B. (2008). Hukum Investasi di Indonesia. Jakarta: Rajawali Pers. h. 151. 
pengawasan, penanaman modal asing mengalami proses mulai dari izin, hingga kewajiban pelaporan.

Proses tersebut diawali dari lembaga yang berwenang untuk mengoordinasikan hingga pejabat yang memberikan persetujuan. Eksistensi lembaga yang mengoordinir investasi, sangatlah memiliki peran strategis di Indonesia. Peran strategis itu untuk menentukan tinggi rendahnya investasi yang masuk, baik oleh lokal maupun asing. ${ }^{7}$

Perusahaan Modal Ventura Asing wajib diatur tentang adanya kewajiban bagi perusahaan yang melakukan Penawaran Umum atau perusahaan yang memenuhi persyaratan sebagai Perusahaan Publik untuk menyampaikan informasi mengenai keadaan usahanya, baik dari segi keuangan, manajemen, produksi maupun hal yang berkaitan dengan kegiatan usahanya kepada masyarakat.

Perusahaan Modal Ventura Asing wajib memberi informasi tersebut mempunyai arti yang sangat penting bagi masyarakat sebagai bahan pertimbangan untuk melakukan investasi. Oleh karena itu, Perusahaan Modal Ventura Asing wajib diatur mengenai adanya ketentuan yang mewajibkan Pihak yang melakukan Penawaran Umum dan memperdagangkan efeknya di pasar sekunder untuk memenuhi Prinsip Keterbukaan.

Kegagalan atas kewajiban tersebut mengakibatkan Pihak yang melakukan atau yang terkait dengan Penawaran Umum bertanggung jawab atas kerugian yang diderita masyarakat dan dapat dituntut secara pidana apabila ternyata terkandung unsur penipuan. Dalam kaitannya dengan itu, Perusahaan Modal Ventura Asing wajib diatur pula kewajibankewajiban yang melingkupi Pihak-Pihak yang berkaitan dengan Penawaran Umum seperti Penjamin Emisi Efek, Akuntan, Konsultan 
Hukum, Notaris, Penilai, dan profesi lainnya, untuk mematuhi kewajibankewajiban yang harus mereka penuhi, disertai dengan ancaman berupa sanksi ganti rugi dan atau ancaman pidana atas kegagalan mematuhi kewajiban yang ada.

Dulunya, koordinasi penanaman modal asing di Indonesia belum terdistribusi dengan baik. Saat itu masih terbagi antara Badan Koordinasi Penanaman Modal (BKPM) dan Badan Koordinasi Penanaman Modal Daerah (BKPMD). Hal seperti ini, dinilai oleh banyak investor berbelit-belit, birokrasi panjang, dan memerlukan biaya yang besar. Kemudian, terbitlah Keputusan Presiden No. 29 Tahun 2004 tentang Penyelenggaraan Penanaman Modal Dalam Rangka PMA dan PMDN melalui Sistem Satu Atap. Keputusan Presiden tersebut akhirnya memberikan wewenang untuk mengoordinasikan penanaman modal di Indonesia hanya BKPM saja. Sistem pelayanan satu atap adalah pelayanan pemberian persetujuan penanaman modal yang pelaksanaan perizinannya terpusat pada satu instansi saja.

Pertimbangan ditunjuknya BKPM sebagai satu-satunya instansi pemerintah yang menangani kegiatan penanaman modal adalah untuk efektivitas investor melakukan investasi di Indonesia. Oleh karena itu, dengan layanan satu atap oleh BKPM, diharapkan pelayanan terhadap investor akan menjadi lebih sufficient. Berdasarkan Keppres tersebut, tugas BKPM mencakup bidang: perencanaan, promosi, perizinan, dan pengendalian penanaman modal. Sedangkan untuk pemerintah daerah hanya berwenang pada izin lokasi, sertifikat hak atas tanah, dan izin mendirikan bangunan.

Setelah diundangkannya Undang-Undang No. 25 Tahun 2007, kewenangan BKPM diperkuat. Dalam Pasal 27 dinyatakan bahwa tugas BKPM meliputi koordinasi antar instansi pemerintah, antar instansi 
pemerintah dengan Bank Indonesia, antar instansi pemerintah pusat dan daerah, serta antar pemerintah daerah. ${ }^{8}$

Pasal 3 Keputusan Presiden No. 29 Tahun 2004 menyatakan bahwa pihak yang berwenang memberikan izin, persetujuan dan insentif penanaman modal asing adalah BKPM. Sementara itu, wewenang pemerintah daerah hanyalah seputar izin teknis di daerah seperti izin mendirikan bangunan, dan sertifikat hak atas tanah. Bagi perusahaan PMA, dikenakan kewajiban untuk melaporkan kegiatannya berupa perkembangan dan kendala yang dihadapi. Lapor tersebut dilaporkan secara berkala kepada BKPM dan pemerintah daerah yang bertanggung jawab di bidang penanaman modal.

Kewajiban pelaporan tersebut di atur lebih lanjut dalam Peraturan Kepala BKPM No. 3 Tahun 2012 Tentang Pedoman dan Tata Cara Pengendalian Pelaksanaan Penanaman Modal. Dalam aturan tersebut dijelaskan bahwa setiap PMA wajib menyampaikan Laporan Kegiatan Penanaman Modal. Laporan itu disampaikan kepada BKPM secara berkala. ${ }^{9}$

Laporan secara berkala tersebut dilakukan dengan dua mekanisme. Pertama, perusahaan yang masih dalam proses konstruksi/tahap pembangunan (belum ada izin usaha), wajib menyampaikan laporan setiap 3 (tiga) bulan sekali. Kedua, apabila telah mencapai tahap produksi/tahap operasi komersial (telah ada izin usaha) maka laporan wajib disampaikan setiap 6 (enam) bulan sekali. ${ }^{10}$

8 Pasal 27 Undang -Undang Nomor 25 Tahun 2007 tentang Penanaman Modal (Lembaran Negara Republik Indonesia Tahun 2007 Nomor 67, Tambahan Lembaran Negara Republik Indonesia Nomor 4724).

${ }_{9}^{9}$ Pasal 1 angka 18 Peraturan Kepala Badan Koordinasi Penanaman Modal Nomor 3 Tahun 2012 tentang Pedoman dan Tata Cara Pengendalian Pelaksanaan Penanaman Modal.

${ }^{10}$ Pasal 11 ayat (2) Peraturan Kepala Badan Koordinasi Penanaman Modal Nomor 3 Tahun 2012 tentang Pedoman dan Tata Cara Pengendalian Pelaksanaan Penanaman Modal. 
Teori Kewenangan berkaitan dengan suatu Negara Hukum. Negara hukum adalah negara yang berlandaskan hukum dan menjamin keadilan bagi warganya. Makdunya adalah segala kewenangan dan tindakan alatalat perlengkapan negara atau penguasa semata-mata berdasarkan hukum atau dengan kata lain diatur oleh hukum. ${ }^{11}$ Pada teori kewenangan dijelaskan bahwa istilah kewenangan disejajarkan dengan bevoegheid dalam istilah Belanda, bahwa "wewenang terdiri atas sekurang-kurangnya mempunyai 3 komponen, yaitu pengaruh, dasar hukum dan komformitas hukum". 4

Komponen pengaruh, bahwa penggunaan wewenang dimaksudkan untuk mengendalikan prilaku subyek hukum; dasar hukum dimaksudkan, bahwa wewenang itu haruslah mempunyai dasar hukum sedangkan komponen komformitas hukum dimaksud bahwa wewenang itu haruslah mempunyai standar.

Kewenangan secara teoritik dapat diperoleh melalui 3 cara, yaitu atribusi, delegasi, dan mandat. Atributie (atribusi) adalah pemberian wewenang pemerintahan oleh pembuat undang-undang kepada organ pemerintahan; Delegasi adalah pelimpahan wewenang pemerintah dari satu organ pemerintahan kepada organ pemerintahan yang lain; sedangkan mandat terjadi ketika organ pemerintahan mengizinkan kewenangannya dijalankan oleh organ lain atas namanya. 5 Bahwa wewenang inilah sesungguhnya yang merupakan legal power yang didalamnya melekat 3 (tiga) unsur, yaitu pengaruh yang memiliki kategori yang eksklusif wajib dipatuhi oleh orang lain dan atau pejabat serta jabatan

${ }^{11 B u s r o, ~ A . D ~ d a n ~ B u s r o, ~ A . B . ~(1993) . ~ A s a s-a s a s ~ H u k u m ~ T a t a ~ N e g a r a . ~ J a k a r t a: ~ G h o i l a ~}$ Indonesia. h. 111.

4 Ibid. h.135.

${ }^{5}$ Hadjon, P.M. (2011). Peradilan Tata Usaha Negara, Tantangan Awal di Awal Penerapan UU No.5 Tahun 1986. Surabaya: Majalah FH Unair, No.2-3 Tahun VI, 201. h.2. 
atau lembaga lainnya, unsur dasar hukum dan unsur komformitas. ${ }^{6}$ Bahwa cara memperoleh wewenang, yaitu melalui: atribusi dan delegasi kadangkadang juga mandat ditempatkan sebagai cara tersendiri untuk memperoleh wewenang" ${ }^{7}$

Berdasarkan teori kewenangan tersebut diatas dalam perspektif kewenangan Otoritas Jasa Keuangan, dalam hal ini memiliki kewenangan mengawasi lembaga keuangan baik bank maupun non bank salah satunya dalam berinvestasi, berdasarkan Undang-Undang No. 21 tahun 2008 tentang Lembaga Otoritas Jasa Keuangan (OJK). Kedudukan Otoritas Jasa Keuangan terhadap perusahaan modal ventura asing dalam melakukan pembiayaan secara langsung di Indonesia berkaitan dengan kewenangan yang dimiliki oleh Otoritas Jasa Keuangan dalam hal Investasi.

Berdasarkan Pasal 6 Undang-Undang No. 21 Tahun 2011 tentang Otoritas Jasa Keuangan, pengawasan yang dapat dilakukan oleh OJK meliputi jasa keuangan pada sektor perbankan, pasar modal, perasuransian, dana pensiun, lembaga pembiayaan dan juga lembaga jasa keuangan lainnya. Jika dikaitkan dengan pembahasan di atas mengenai modal ventura, maka modal ventura dapat kita kategorikan sebagai lembaga pembiayaan. Menurut Peraturan Presiden No. 9 Tahun 2009 tentang Lembaga Pembiayaan, yang termasuk ke dalam jenis lembaga pembiayaan antara lain adalah perusahaan pembiayaan, modal ventura dan perusahaan pembiayaan infrastruktur.

Dari beberapa penjelasan yang ada sebelumnya dapat ditarik kesimpulan bahwa pengawasan terhadap perusahaan modal ventura dilakukan oleh Otoritas Jasa Keuangan. Menurut Peraturan Menteri Keuangan Nomor 18/PMK.010/2012 tentang Perusahaan Modal Ventura,

${ }^{6}$ Ridwan, HR. (2012). Hukum Administrasi Negara. Yogyakarta: UII-Press. h.74.

7 Atmaja. (2013). Hukum Antar Wewenang, Konsep dan Cara Penyelesaian. Denpasar:Makalah FH-UNUD. h.5. 
perusahaan modal ventura haruslah berbentuk badan hukum perseroan terbatas atau koperasi seperti yang diatur dalam Pasal 11 ayat (1) aturan tersebut.

Bagaimana jika badan hukum atau badan usaha asing yang akan melakukan usaha pembiayaan modal ventura asing di Indonesia. Penggolongan perusahaan modal ventura asing dalam peraturan per Undang-Undangan didasarkan pada kepemilikan saham PMV tersebut. Pasal 7 Peraturan Presiden No. 9 Tahun 2009 menyebutkan saham perusahaan modal ventura dapat dimiliki oleh warga negara Indonesia, badan hukum Indonesia, dan badan usaha asing.

Lebih lanjut di dalam turunannya, Peraturan Menteri Keuangan No. 18/PMK.010/2012 ada istilah Joint Venture (Perusahaan Patungan), yaitu PMV yang sebagian kepemilikannya terdapat penyertaan langsung badan usaha asing. Artinya, saham PMV yang memiliki unsur asing, tidak dapat dimiliki oleh perseorangan, melainkan haruslah berbadan hukum di negara asalnya. Mengenai keorganisasiannya, lembaga pembiayaan/perusahaan modal ventura haruslah berbentuk Perseroan Terbatas atau Koperasi. ${ }^{12}$

Khusus untuk PMV asing, ia hanya bisa beroperasi dengan bentuk Perseroan Terbatas. Itu artinya, apabila ada PMV asing yang ingin melakukan pembiayaan secara langsung, maka ia harus menjadi badan hukum Indonesia terlebih dahulu. Berdasarkan Pasal 11 ayat (2) Peraturan Menteri Keuangan Nomor 18/PMK.010/2012 tentang Perusahaan Modal Ventura partisipasi asing dalam pembiayaan modal ventura dilakukan dengan bentuk Perseroan Terbatas. Dalam peraturan menteri tersebut, objek pengawasan yang dilakukan oleh OJK terhadap aktivitas PMV hanya

12 Pasal 6 Peraturan Presiden Nomor 9 Tahun 2009 tentang Lembaga Pembiayaan jo. Pasal 11 Peraturan Menteri Keuangan Nomor 18/ PMK.010/2012 tentang Perusahaan Modal Ventura, "PMV didirikan dalam bentuk badan hukum perseroan terbatas atau koperasi". 
terbatas pada PMV Indonesia (koperasi atau perseroan terbatas). Implikasinya, OJK tidak dapat mengawasi PMV asing yang melakukan pembiayaan secara langsung, karena itu merupakan kewenangan BKPM.

Undang-Undang No. 21 Tahun 2011 tentang Otoritas Jasa Keuangan, Peraturan Presiden No. 9 Tahun 2009 tentang Lembaga Pembiayaan, serta Peraturan Menteri Keuangan Nomor 18/PMK.010/2012 tentang Perusahaan Modal Ventura, merupakan landasan yuridis atas suatu kedudukan Otoritas Jasa Keuangan terhadap perusahaan modal ventura asing dalam melakukan pembiayaan secara langsung di Indonesia. Efektifitas Undang-Undang No. 21 Tahun 2011 tentang Otoritas Jasa Keuangan, Peraturan Presiden No. 9 Tahun 2009 tentang Lembaga Pembiayaan, serta Peraturan Menteri Keuangan Nomor 18/PMK.010/ 2012 tentang Perusahaan Modal Ventura, dapat berjalan efektif, bila dapat memenuhi unsur efektifnya kaedah hukumnya.

Bahwa bentuk keberlakuan kaedah hukum yakni keberlakuan empiris, normatif dan evaluatif. 13 Bila ditelaah lebih mendalam, agar kaedah hukum itu berfungsi, maka suatu kaedah hukum harus memenuhi berlaku secara yuridis, berlaku secara sosiologis, dan berlaku secara filosifis, maka mungkin kaedah hukum tersebut hanya merupakan hukum yang dicita-citakan (ius constituendum). ${ }^{14}$ Kaedah hukum atau peraturan tertulis benar-benar berfungsi senantiasa dapat dikembalikan pada paling sedikit 5 (lima) faktor sebagai berikut: ${ }^{15}$

1. Faktor kaedah hukum atau peraturan itu sendiri;

2. Faktor penegak hukum yakni pihak-pihak yang membentuk maupun menerapkan hukum;

${ }^{13}$ Bruggink, J.J.H., Arief Sidharta. (2000). Refleksi Tentang Hukum. Bandung: PT. Citra Aditya Bakti. h.147-153.

${ }^{14} \mathrm{Ibid}$. h. 21.

15 Soekanto, S. (2000). Faktor-Faktor Yang Mempengaruhi Penegakan Hukum. Jakarta: CV. Rajawali. h. 5. 
3. Faktor fasilitas dan sarana yang diharapkan akan dapat mendukung pelaksanaan kaedah hukum;

4. Faktor warga masyarakat yang terkena ruang lingkup peraturan tersebut dan

5. Faktor kebudayaan, yakni sebagai hasil karya, cipta dan rasa yang di dasarkan pada karsa manusia di dalam pergaulan hidup.

Kelima faktor tersebut di atas saling berkaitan dengan eratnya, oleh karena merupakan esensi dari penegakan hukum, serta juga merupakan tolak ukur dari pada efektifitas penegakan hukum, sehingga efektifitas Undang-Undang No. 21 Tahun 2011 tentang Otoritas Jasa Keuangan, Peraturan Presiden No. 9 Tahun 2009 tentang Lembaga Pembiayaan, serta Peraturan Menteri Keuangan Nomor 18/PMK.010/2012 tentang Perusahaan Modal Ventura dapat berjalan efektif.

\section{Kesimpulan}

Bahwa perusahaan modal ventura asing yang melakukan penanaman modal secara langsung di Indonesia merupakan salah satu bentuk penanaman modal asing. Hal itu tidak lepas dari luasnya ruang lingkup modal asing, yang diartikan sebagai modal dimiliki oleh negara asing, perseorangan warga negara asing, badan usaha asing, badan hukum asing, dan/atau badan hukum Indonesia yang sebagian atau seluruh modalnya dimiliki oleh pihak asing. Pengawasan terhadap penanaman modal asing dilakukan oleh Badan Koordinasi Penanaman Modal sesuai dengan ketentuan Undang-Undang No. 25 Tahun 2007 tentang Penanaman Modal. Sesuai dengan ketentuan dalam Permenkeu No. 18/ PMK/0.10/2012 memaparkan bahwa ruang lingkup pengawasan modal ventura yang dilakukan oleh OJK hanya terbatas pada PMV Indonesia (Koperasi atau Perseroan Terbatas). Implikasinya, OJK tidak dapat mengawasi PMV asing yang melakukan pembiayaan secara langsung, 
karena itu merupakan kewenangan BKPM. Dikarenakan aktivitas pembiayaan oleh perusahaan modal ventura asing memiliki aturan yang bersinggungan maka sudah sepatutnya peraturan modal ventura asing mengikut kepada satu aturan spesifik saja. Sebagaimana diketahui aktivitas modal ventura diatur dalam Peraturan Presiden No. 9 Tahun 2009 jo. Peraturan Menteri Keuangan Nomor 18/PMK/0.10/2012 merupakan turunan dari Undang-Undang No. 40 Tahun 2007 tentang Perseroan Terbatas, sedangkan penanaman modal asing diatur dengan UndangUndang No. 25 Tahun 2007 tentang Penanaman Modal. Pengaturan mengenai lembaga pembiayaan hanya diatur dalam Peraturan Presiden. Walaupun secara hierarkis, status dari Perpres tersebut adalah peraturan pelaksana dari Undang-Undang, substansi yang diaturnya tidak identik dengan ketentuan Undang- Undang yang memerintahkannya. Oleh karena itu, harusnya ketentuan mengenai aktivitas pembiayaan haruslah diatur dalam Undang-Undang tersendiri.

\section{DAFTAR PUSTAKA}

Atmaja. (2013). Hukum Antar Wewenang, Konsep dan Cara Penyelesaian. Denpasar: Makalah FH-UNUD.

Bruggink, J.J.H., Arief Sidharta. (2000). Refleksi Tentang Hukum. Bandung: PT. Citra Aditya Bakti.

Busro, A.D dan Busro, A.B. (1993). Asas-asas Hukum Tata Negara. Jakarta: Ghoila Indonesia.

Hadjon, P.M. (2011). Peradilan Tata Usaha Negara, Tantangan Awal di Awal Penerapan UU No.5 Tahun 1986. Surabaya: Majalah FH Unair, No.2-3 Tahun VI

Halim, A. (2003). Kamus Lengkap 1 Milyar Inggris-Indonesia. Surabaya: Sulita Jaya

Marzuki, P.M. (2005). Penelitian hukum. Jakarta: Prenada Media 
Ridwan, HR. (2012). Hukum Administrasi Negara. Yogyakarta: UII-Press.

Salim HS dan Sutrisno, B. (2008). Hukum Investasi di Indonesia. Jakarta: Rajawali Pers.

Soekanto, S. (2000). Faktor-Faktor Yang Mempengaruhi Penegakan Hukum. Jakarta: CV. Rajawali.

Sornarajah, M. (2010). The International Law on Foreign Investment. 3rd Edition. New York: Cambridge University Press.

Supanca, I.B.R. (2006). Kerangka Hukum dan Kebijakan Investasi Langsung di Indonesia. Bogor: Ghalia Indonesia. 